\title{
Honest Development Characters Which Are Karma Phala Values
}

\author{
Ketut Dharsana ${ }^{1}$, Wayan Eka Paramartha ${ }^{2}$, Gede Nugraha Sudarsana ${ }^{3}$ \\ \{iketut.dharsana@undiksha.ac.id ${ }^{1}$,wayan.eka.paramartha@gmail.com ${ }^{2}$, playgede@gmail.com ${ }^{3}$ \} \\ ${ }^{123}$ Universitas Pendidikan Ganesha, Indonesia
}

\begin{abstract}
This study aimed at developing honest characters contained in the values of Karma Phala. it was an action research with sample made of high-school students in Singaraja. The sample was taken by means of purposive sampling technique while honest character data was collected using a questionnaire analysed descriptively. The result show that an increase in the ability to promote character education with regard to Karma Phala values ensures planned, systematic, continuous, and measurable implementation in schools. Since Karma phala is often confused with the values applying in Balinese society, it is recommended that RPBK be used as an instrument in implementing plans for guiding and counselling services in schools.
\end{abstract}

Keywords: Honest Characters, Karma Phala, Guidance and Counseling.

\section{Introduction}

The high and low quality of education, is not only influenced by the government but also on the other related components in education [1]. Such components include counseling teacher as a motivator a learning motivator, providing space for students to express themselves [2]. The school often hope students will become human beings of noble characters and behaviors[3].

Character education is indispensable to students, especially honest personality values. It is very important to develop character of students, a provision in navigating life in the future [4]. Honesty is one of the most important character values that must be evident in a student. Indonesia is among the world nations that still maintains eastern culture, where values and morals are dominant to the extent that the character and identity of the nation depends on value and morality itself [5].

Honest is acknowledging, saying or giving information that is in accordance with reality and truth [6], [7], [8], [9], [10], [11]. Honest characters can be directly visible in the classroom, for example, when students seat for their exams [12]. Behavior such as cheating is an act that reflects dishonesty to oneself, friends, parents and educators [13]. The development of honest character in school can be indicated by such indicators as: 1) not copying from each other, 2) telling the truth about something just experienced, 3) wanting to express their opinions and accepting friends' perceptions.

In most places, especially in Bali, the word honest is better known as satyam [14]. This refers to exact or Supreme Truth (highest truth) and Satyam should be a milestone in the direction of everything done, thought about, or said [15], [16], [17]. In Hindu teachings, honesty 
produce results often called Karma Phala. The law of Karma Phala is a philosophy that contains ethics Hindus believe in the results in an act [18].

Hindus in Bali are well acquainted with the law and whole concept of Karma Phala (karma: deeds, phala: fruit/yield), one of the basic beliefs [19], [20], [21]. According to the teachings of Karma Phala, every human action has positive or negative results. The teachings very closely relate to the beliefs about reincarnation, from its teachings, human condition (both joy and sorrow) is caused by the results of actions did in the course of life [22], [23]. In this teaching, it can be said that humans determine their fate while God determines when the results are given (both during life and after reincarnation). The law of karma as part of Hinduism applies to anyone and anything. There are no exceptions in "karma, and who sows will reap" (sapa nandur bakal ngunduh, ngunduh wohing pakart) [19].

The law of karma gives rise to samsara, a circle that assembles, lives, dies, reborn, lives again, and dies again and so on. In the new life, the human condition depends on the nature and actions of past-life [24]. If people do well, they will be rewarded with kindness in future life, and if they do evil, they will be hurt in later life.

There is a guide who always reminds of the relationship between karma or deeds and phala that guides human behavior towards Tri Kaya Parisudha as integrated manacika, wacika, and kayika or the union of good thoughts, words, and actions [18].

In the implementation of character education, the values of the local culture are contents easy to use because they are invested in the school [25]. The Balinese culture, for instance, Karma Phala, is a strong value of local wisdom that can be inculcated in students [26]. The counseling teacher provides understanding related to the honest character contained in the values of Karma Phala. This ensures students will get information and knowledge of character education from Karma Phala values, honest character development.

\section{Method}

The efforts to address lack of optimal planning for the implementation of counseling services at Sukasada 1 Public High School include the assistance in reviewing education services or its implementation in the preparation of Classical Guidance RPBK, RPBK Guidance, RPBK Group Counseling and RPBK Individual Counseling to BK teachers (counseling guidance teacher). The following is a figure of the design of the activities to be carried out:

PREPARATION:

Socialization Seminar and workshop through Focus Group Discussion (FGD) about materials RPBK
IMPLEMENTATION AND ASSISTANCE 


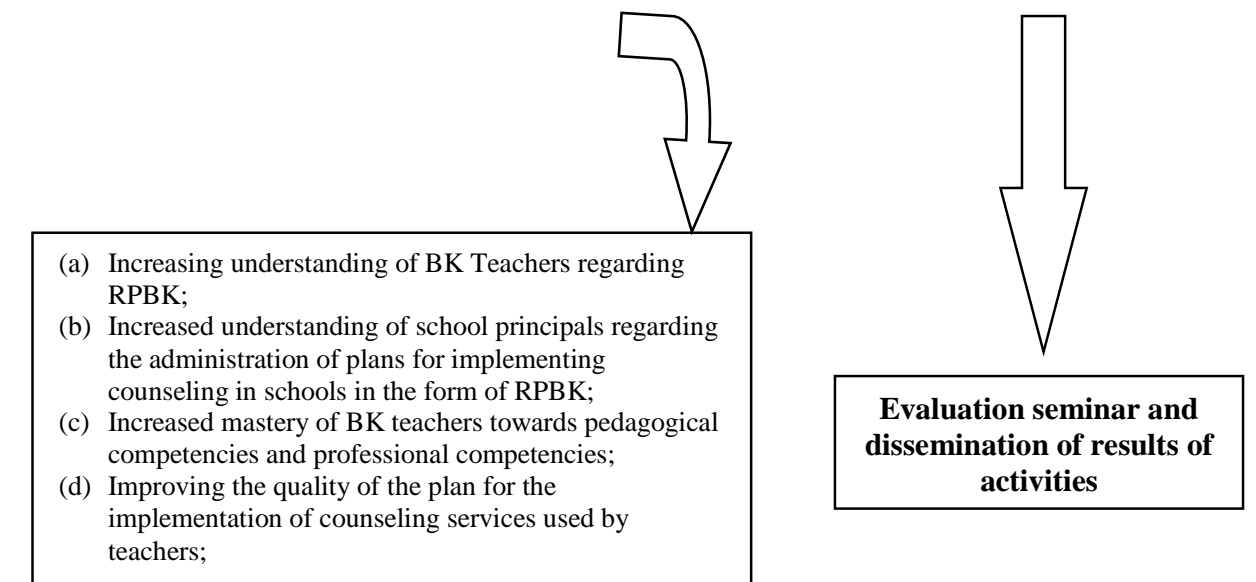

Fig. 1. Methods of implementing a study-based Assistance in the act of education and counseling services at the School

From figure 1, the stages of Counseling-based Mentoring in education and related services are as follows: (1) socialization seminars and workshops through Focus Group Discussion (FGD) on RPBK materials, which will (a) Improve the understanding of BK Teachers related to RPBK, (b) Increase the understanding of school principals based on the management of plans for implementing counseling in schools in the form of RPBK, (c) Increase BK teachers' mastery of pedagogical and professional competencies, (d) Improve the quality of counseling services; (2) implementation of mentoring in one cycle; (3) evaluation seminar and dissemination of the results of activities.

The FGD was conducted with the principal, all teachers and employees of SMAN 1 Sukasada. The topics discussed in the FGD are (1) how to implement honest character development in building school and class cultures, and the implementation of character-filled learning, (2) content of character values according to Karma Phala values, (3) measurement instruments character education and how to implement it. Since the guest speakers in this FGD are the service experts of education, Balinese cultural thinkers of honest character values according to the principles of Karma Phala.

FGD with parents on the implementation of character education to their children was conducted. It was to support the acculturation of character values both at school, at home and in the community.

The determination of the instrument for measuring the impact of character education produced was successful. The assistance was carried out to guide the implementation of honest character development in building school and class cultures. Through the assistance process, it is expected that character education will continue, giving the pattern of implementation. The measurements are made using instruments produced in the FGD.

\subsection{Instructional Media}

In this case, the media will be used to carry out mentoring activities related to the implementation of counseling plans at SMAN 1 Sukasada, in the following ways: 
1. Papers and RPBK as a source of written information that will be provided to the BK Teachers who participate in this gathering activity;

2. Power Point as a medium for presenting materials to be delivered to the BK teacher;

3. Monitoring Guidelines as instruments for determining the level of understanding and skills of BK Counselors in preparing RPBK.

Character education instruments to be used included:

1. Character education instruments related to school culture and class. They include questionnaires filled by teachers, employees, and students. This instrument measures behavior related to honesty.

2. Honest culture-based local character instruments (Karma Phala values) included questionnaire filled out by Teachers, Employees and students. It measured character related to honest (satya), implemented in school and class cultures, as well as in the implementation of learning. All of that can be seen from the attitude and behavior towards academics. The datasets of this research can be accessed from https://osf.io/gr6cx/ from the Open Science Frameworks.

The evaluation of the successful implementation of character education during was carried out by the observation method. Observations are carried out using an observation-sheet. Implementation evaluation was done during the actual community service. The community service is said to be successful if: (1) the results of the implementation are minimally categorized and (2) the character of the school community (teachers, employees, and minimal students) become entrenched

\section{Result}

There were positive responses from training of participants as well as on the questionnaires addressing the impressions, suggestions, criticisms and proposals for the exercise. Increased ability of BK teachers, in the process of implementing character education through honest character development strategies based on Karma Phala values, ensuring the implementation of character education in schools is planned, systematic, continuous, and measurable. Improving the ability of BK teachers in using measuring tools or character assessment instruments in valuing school culture, class culture, and learning activities in improving the character of students ensures teachers know the progress achieved in establishing the school, class character learning cultures.

\section{Conclusion}

It can be concluded that there is an increase in honest character with the values of Karma Phala as outlined in the administration planning counseling service by the BK teacher through Counseling Guidance Service Plan (RPBK) at school.

\section{References}

[1] M. Mustari and M. T. Rahman.: Manajeme Pendidikan. Jakarta: Raja Grafika Persada (2014) 
[2] R. H. Nasution.: Peningkatan Keterampilan Proses Sains Dan Hasil Belajar Melalui Pembelajaran Berbasis Laboratorium Pada Siswa Kelas VIII SMP Negeri 1 Pekalongan Lampung Timur, Universitas Lampung (2014)

[3] N. Khoirunisa.: Implementasi Kurikulum 2013 Mata Pelajaran Aqidah Akhlak Dalam Membentuk Karakter Siswa Kelas 1a Di Sekolah Dasar Islam Terpadu (Sdit) Muhammadiyah Al-Kautsar Kartasura Kabupaten Sukoharjo Tahun 2015," Universitas Muhammadiyah Surakarta (2015)

[4] A. Majid.: Pendidikan Karakter Menurut K.H. Hasyim Asy'ari Dalam Kitab Adab Alalim Wa-al Muta'allim,” Institut Agama Islam Negeri Salatiga (2016)

[5] M. Yunus.: Upaya Guru Membentuk Karakter Bangsa Pada Anak Usia Dini Melalui Proses Pembelajaran Di Yayasan Raudatul Athfal (Ra) Fathun Qarib," Serambi Akad., vol. III, no. 2, pp. 174-182 (2015)

[6] T. Carlsson, G. Bergman, U. M. Marttala, B. Wadensten, and E. Mattsson.: Information Following a Diagnosis of Congenital Heart Defect: Experiences Among Parents to Prenatally Diagnosed Children," PLoS One, vol. 10, no. 2, p. e0117995 (2015)

[7] D. Waskul.: The Importance of Insincerity and Inauthenticity for Self and Society: Why honesty is Not The Best Policy. Authenticity in culture, self, and society (2009)

[8] H. Noble, J. E. Price, and S. Porter, "The Challenge to Health Professionals When Carers Resist Truth Telling at The End Of Life: A Qualitative Secondary Analysis," J. Clin. Nurs., vol. 24, no. 7-8, pp. 927-936 (2015)

[9] J. R. Eiser and J. van der Pligt, Attitudes and decisions, 1st Editio. London: Psychology Press (2015)

[10] M. Platts, Reference, Truth and Reality: Essays on The Philosophy of Language, 1st Editio. London: Routledge (2016)

[11] K. Nakayachi, B. B. Johnson, and K. Koketsu, "Effects of Acknowledging Uncertainty about Earthquake Risk Estimates on San Francisco Bay Area Residents' Beliefs, Attitudes, and Intentions," Risk Anal., vol. 38, no. 4, pp. 666-679 (2018)

[12] I. M. Shahid, A. Sastromiharjo, and D. S. Anshori, "Pengaruh Pendidikan Karakter Berbasis Leasson Study Terhadap Keterampilan Menulis," in International Conference on Education Language and Literature, 2018, vol. 1, no. 1, pp. 294-302.

[13] A. Ardinansyah, D. Tenrisau, F. Aslim, and I. S. Wekke, "Ketidakjujuran Akademik Dalam Pendidikan Tinggi," ResearchGate, no. 20 (2018)

[14] I. W. S. Yasa, "Gandharwa Weda : Memahami Prinsip Kerja Kreatif Mpu Kanwa 1," Dharmasmrti, vol. I, pp. 1-134 (2018)

[15] M.-W. Liu, “A Chinese Madhyamaka Theory of Truth: The Case of Chi-tsang,” Philos. East West, vol. 43, no. 4, pp. 649-67 (1993)

[16] I. A. G. Yadnyawati, "Dharma; Our Main House," Voice Intellect. Man-An Int. J., vol. 7, no. 2, pp. 1-8 (2017)

[17] M. Suarta.: Wacana-wacana Filosofis Bali dalam Pertunjukan Arja Rri Denpasar Lakon Payuk Prungpung, Suarta, M. Wacana-wacana Filos. Bali dalam Pertunjuk. Arja Rri Denpasar Lakon Payuk Prungpung. Linguist. Bul. Ilm. Progr. Magister Linguist. Univ. Udayana, vol. 17, pp. 1-19 (2010)

[18] R. Fahmi.: Sistem Religi Masyarakat Bali dalam Novel Sukreni Gadis Bali Karya AA Pandji Tisna, J. Keilmuan Bhs. Sastra Pengajarannya, vol. 1, no. 1, pp. 96-107 (2015)

[19] I. G. S. Widnyana.: Persepsi Umat Hindu Terhadap Ajaran Karmaphala Dalam Teks Agastya Parwa di Desa Songan Kintamani Bangli,” J. Penelit. Agama Hindu, vol. 1, no. 2, pp. 448-453 (2017)

[20] A. Bakar, “Konsep Ibadah dalam Hindu," Toleransi, vol. 4, no. 2, pp. 195-205, 2012. 
[21] A. Wiguna, "Mengurai Nilai-Nilai Moral Dalam Satua Sebagai Media Pendidikan Karakter di Era Global," in Prosiding Seminar Nasional Kearifan Lokal Indonesia untuk Pembangunan Karakter Universal 2015, 2018, pp. 232-241.

[22] N. B. Atmadja, A. T. Atmadja, and T. Maryati, "Rutinitas Keseharian Padamasyarakat Hindu di Bali," in Proceeding SENARI 3, 2015, pp. 319-324.

[23] I. M. R. Arta, "Nilai-Nilai Kultural Bali dalam Novel: Telaah Sastra Feminis dan Relevansinya Sebagai Bahan Pembelajaran Sastra di Sekolah," in Seminar Nasional Bahasa, Sastra, dan Pengajarannya, 2018, pp. 211-218.

[24] I. W. Nitayadnya, "Hukum Karma Dalam Novel Sukreni Gadis Bali Kajian Rekonstruksi dan Refleksi," Sawerigading, vol. 18, no. 1, pp. 1-14 (2012)

[25] M. Nadlir, "Urgensi Pembelajaran Berbasis Kearifan Lokal," J. Islam. Educ. Stud., vol. 2, no. 2, pp. 299-330 (2014)

[26] I. W. Rasna.: Nilai Kearifan Lokal Cerita Rakyat Bali Yang Relevan Untuk Pendidikan Karakter Siswa SD Kelas I," in Seminar Nasional Riset Inovatif (SENARI) Ke-4, 2016, pp. 711-723 (2016) 